\title{
Institutionalizing Community-Based Research in Indonesian Islamic Higher Education: Two Cases from the Sunan Ampel State Islamic University Surabaya and Alauddin State Islamic University Makassar
}

\author{
Mohammad Hanafi, Djuwairiah Ahmad
}

\begin{abstract}
The article presents a reflective experience on the institutionalization of community-based research in Indonesian Islamic Higher Education. It comprises two case studies from two different universities, the Sunan Ampel State Islamic University Surabaya and the Alauddin State Islamic University Makassar. Both are the two selected partners within the Supporting Islamic Leadership in Indonesia (SILE)/Local Leadership Development (LLD) Project in partnership between Indonesian Ministry of Religious Affairs and Canadian International Development Agency. The project introduces community-based research as an approach to engage community through Tridharma (Three mandates) of Higher Education. The institutionalization covers various activities from raising awareness, building capacity, to developing institutional policy at a national level. The cases show that the different socio-historical context and political dynamic of each campuses influence the process, challenge and response to the institutionalization. However, both campuses share similar reasons for adopting community-based research from the Islamic perspective, namely that using research as a means of promoting social change is consistent with the Qur'anic principles and the Prophetic tradition.
\end{abstract}

KEYWORDS community-based research, institutionalization, Islamic higher education, Islamic values, social transformation.

The genesis of the institutionalization of community-based research (CBR) in Indonesian Islamic higher education came with the launch of the Supporting Islamic Leadership in Indonesia (SILE)/Local Leadership for Development (LLD) Project (2011-2017). The project was funded by the Government of Canada through the Canadian International Development Agency (CIDA, now Global Affairs Canada). It was a multi-level governance project involving national and local governments. At the national level, the Ministry of Religious Affairs (MORA) was the lead Indonesian project partner serving as Co-chair of the project's Joint Steering Committee. At the provincial level, two universities under the Directorate of Islamic Higher Education, Sunan Ampel State Islamic University Surabaya (UIN Sunan Ampel) and Alauddin State Islamic University Makassar (UIN Alauddin), were selected as partner institutions working collaboratively with local communities and civil society organizations. 
The project's chief purpose was to build the capacity of the two universities in implementing their outreach to local communities. A related goal was to build the capacity of the Ministry of Religious Affairs (MORA) to effectively integrate democratic governance practices in their strategies, programs and budgets that support university outreach programs.

The SILE/LLD Project introduced a new model for community engagement through partnership. It initiated a range of activities that included training workshops, coaching, worksessions, internships, scholarships, conferences, and other similar activities both in Indonesia and in Canada. The participants included individuals from local and national organization partners. For example, many lecturers, faculty members, and university administrators took part in project activities, as did decision-makers from the Directorate of Islamic Higher Education within the Ministry of Religious Affairs, and members of community service organizations and other community leaders.

One of the most significant benefits of the program related to community-based research (CBR). CBR is a collaborative approach to research among different partners but with community members as the main partner. Hence, CBR is more about research with, by, and for the community, rather than on or about the community. It is more than a tool for community involvement - instead, it is a process of sharing power with and empowering community members to attempt social action and social change for social justice.

This article describes how the CBR capacity-building experience was translated into institutionalized policy and practice within two State Islamic Universities (UIN) in Indonesia: UIN Sunan Ampel in the city of Surabaya and UIN Alauddin in the city of Makassar. The concept of institutionalization here refers to the deliberate efforts of establishing and sustaining CBR learning outcomes in the form of individual attitudes, knowledge and skill into institutional policy governance and corresponding practice. This is a reflective article about an institutionalization process in which we were active participants.

\section{Two Cases of Community-Based Research Institutionalization}

\section{Case 1: The Sunan Ampel State Islamic University Surabaya}

The Sunan Ampel State Islamic University Surabaya (UIN Sunan Ampel) is one of 55 staterun Islamic Higher Education Institutes (IHEI) and one of 644 IHEIs across the country of Indonesia. The university acts as a coordinator for 160 of the private IHEIs in four different neighboring provinces, East Java, Bali, Easter Nusatenggara, and Western Nusatenggara. In East Java alone there are 137 IHEIs. The university is located in Surabaya, the country's second largest city after Jakarta. The population of the city is about 2,806,306 people living within 326 square kilometres. Surabaya is the capital of East Java Province.

Since its establishment in 1961, the university has been known for its community engagement work. At that time, local community and religious leaders proposed the establishment of a higher education institution in order to develop the Ummah (Islamic community). In particular, the university was to be responsible for the growth and maturation of Indonesian society and to generally elevate national self-esteem after prolonged colonialization for 3.5 centuries

Engaged Scholar Journal: Community-Engaged Research, Teaching, and Learning 
by European countries, mostly The Netherlands, and later by Japan. The main disciplines developed within the institution were Islamic-traditional sciences, such as Qur'anic exegesis, Hadith studies, Arabic literature, Islamic history, education, theology, philosophy, and Sufism. The educational system looked to Al-Azhar University in Egypt as a model with a focus on normative and theological studies. The local Muslim community was approached as a target of Islamic propagation (dakwah). Community education and development followed a missionary model, mostly through preaching and charity.

\section{Community Engagement in UIN Sunan Ampel}

Major changes occurred in the system of teaching IHE across Indonesia in the early 1990's. At this time the first alumni of the Indonesia-Canada Islamic Higher Education Project (ICIHEP) held at the Institute of Islamic Studies at McGill University in Montreal Canada returned to Indonesia. Even though the project involved only two State Institutes of Islamic Studies in Jakarta and Yogyakarta, the impact of this modernization of education system spread over other IHE institutions. The Directorate of Islamic Higher Education under MORA played a significant role in disseminating this new modern tradition through its strong coordinative system. UIN Sunan Ampel was one of the most influenced institutions. The university started to apply a rational-Eurocentric approach to Islamic studies. In what was known as the "New Order era", the community was treated more as an object, rather than a partner, of research. The main model of community engagement was by extension through student placements in a community program called Kuliah Kerja Nyata (KKN, literally "real work learning") which dated back to 1951 of the Old Order Era. This was the first era of Indonesia after the Independence Day, August 17, 1945 when the nation was led by Soekarno, the first president of the Indonesia Republic. The era ended in 1966 and was replaced by the New Era, led by the second president, Soeharto, until 1998.

The next Indonesian Reform Era in the late 1990's and early 2000's signaled a significant change in the community-university approach that took place within the environment of Islamic higher education. Some Indonesian Muslim scholars criticized the educational system as too Eurocentric with its universal scientific methodology. These scholars felt the need to challenge the current stream by introducing decolonizing methodologies in teaching, research, and community service. Working with the Indonesian Society for Social Transformation (INSIST), the Directorate of Islamic Higher Education started to introduce participatory action research (PAR) in 2003. Some IHEI's were reluctant to accept this approach because of what they understood to be a close relation between PAR and Socialist, Marxist and Leftist ideology. Nonetheless, UIN Sunan Ampel and a few other institutions applauded the approach as a sound methodology to transform Muslim communities. The reason behind this acceptance was the common goal of developing communities from within through community empowerment, facilitation and organization. Community services taking place through the university expanded beyond narrowly defined religious matters, touching on broader community livelihood as well.

Some of the religious reasons behind the acceptance of PAR can be found in the 
Islamic epistemological sources, primarily the Qur'an (the record of the revelation received by the Prophet Muhammad) and Hadith (accounts of the word and deeds of the Prophet Muhammad), and the derivatives are Ijma' (recording consensus of a community of scholars) and Qiyas (reports of reasoning by literary analogy). Some verses of the Qur'an taken as support for CBR are "Their (i.e. Muslims') affairs are conducted by consultation among them" (42:38), "Surely God does not change the condition of a people until they change their own condition"(13.11), "O you who have believed, fear Allah. And let every soul look to what it has put forth for tomorrow - and fear Allah. Indeed, Allah is acquainted with what you do" (53:18). In addition, the sayings of the Prophet Muhammad recorded in the Hadith, were also instructive: "You have better knowledge (of a technical skill) in the affairs of the world" (Sahih Muslim: Book 30, Hadith \#5832); "The best people are the most beneficent ones" (Al-Tabrani, al-Mu'jam al-Awsat?, \#5937); a saying from Umar ibn Abd alAziz, "The acts of someone without knowledge harm more than they benefit" (Imam Ahmad, Kitaab'uz Zuhd, \#1737); and some other reasons come from traditional scholarly religious teaching such as "Knowledge without action is insanity and action without knowledge is vanity" (Al-Ghazali, Ayyuhal Walad, 17).

From a political point of view, the timing was right to implement PAR, especially through Kuliah Kerja Nyata (KKN), because it was no longer supported financially by the national government. The government was perceived as a part of the problem within communities because the aid it provided to communities created an unhealthy dependency. It was therefore necessary to avoid working too closely with government bureaucracy. Rather, the primary focus was on marginalized communities at the local level. The implementation of PAR was primarily meant to strengthen the community service function of the university. It challenged the charity approach to community engagement and replaced it with more of a social justice orientation. In part, PAR was designed as a built-in curriculum within the university for learning about and carrying out community service. In turn, the university became recognized as a resource institution regarding how to develop community service via the PAR methodology. Central to the university's adoption of PAR was the conviction, supported by religious principles that the university has a responsibility to serve and engage the community in order to transform it into a prosperous, just and equitable society.

Participatory Action Research as a Critical Avenue for the Institutionalization of Community-Based Research

The mainstreaming of PAR within UIN Sunan Ampel provided both a challenge and an opportunity to the introduction of community-based research (CBR). For some people, the concepts of PAR and CBR were similar, simply variant expressions of the same research approach. For these people it was a matter of naming. Borrowing William Shakespeare's frequently referenced line in Romeo and Juliet, "a rose by any other name would smell as sweet", their attitude could be described as such. However, this opinion was not shared across faculty members in the university. Some faculty members treated PAR as more than a research methodology; it was an ideology to work with community. Therefore, they felt alarmed and threatened when the SILE/LLD Project introduced new approaches and methodologies, especially from Western-Northern countries such as Canada. They perceived this as another form of colonization. However, most faculty members were less defensive in their assessment, 
viewing the relationship between PAR and CBR as a matter of strategic options, just as in Islamic belief where the Prophet Jacob once asked his sons to take different approaches or ways to enter Egypt when they had to meet their long-lost bother, Prophet Joseph, just in case one strategy did not work out.

The first approach to community service and building community partnerships introduced by the SILE/LLD Project was asset-based community development (ABCD) training delivered by the Coady International Institute from Antigonish, Canada. The debate between an asset-strength-based versus a problem-deficit-based thinking had begun. However, PAR was the only methodology or model previously applied in KKN. Now that the institute had two models, a new challenge arose about how to implement this new learning within the well-established KKN system that had adopted PAR. ABCD was subsequently piloted in a community-university partnership initiative through eight small working groups comprised of university and community organization partners.

The new learnings that resulted from the ABCD partnership pilots, combined with the long practice of working with community through PAR, made the university more dynamic. Previously, the university had considered itself as the only authoritative institution in producing knowledge. It was this new dynamic community engagement story that the university wanted to disseminate to a wider audience. As a result, in 2013 the university had an opportunity to present their experiences at CUExpo in Newfoundland, Canada. This international Expo encouraged participants to share differences and similarities in community engagement around the world. Many different approaches and theories relating to community-university cooperation and partnerships were presented and discussed. While admitting to the existence of disparities among them, the participants at the conference still managed to discern a common thread across all the innovations.

Unity in diversity, or Bhineka Tunggal Ika in Sanskrit as is the Indonesian national motto, is an accurate phrase to describe what happened during the CUExpo conference. CBR was one concept discussed at the event, and which seemed inclusive and accomodating of differences among the various community-determined, participatory and action-oriented research traditions (including PAR). The encounter with CBR as a technical term in research became an insightful experience to help navigate the conflict between PAR and ABCD back home in the university. For example, CBR helped to frame how the PAR emphasis on needs assessment could be complemented with ABCD's emphasis on resource assessment.

Another learning experience that helped to navigate perceived contradictions in approach was the Community-Engaged Scholarship internship program housed at the Institute for Community-Engaged Scholarship (ICES) at the University of Guelph, Canada, an institute sharing our own university's goal of democratic community development. As with the discussions at the CUExpo conference, community-engaged scholarship is a concept that covers all three university mandates of research, teaching and community service. The concept was useful in integrating the three mandates into one in which the community is engaged with the university. For example, service learning could be applied as a teaching method, and its activity could be combined with CBR which could lead to community service. 
The experiences from CUExpo and ICES provided too much information in a very short time period. It seemed that the exposure was only at the surface level. After returning home from experiencing the "global movement" of community-university engagement at CUExpo, the time came to share our learnings. Some faculty members welcomed the ideas, taking them for granted. Others, especially the proponents of PAR, challenged the ideology and theory behind those community-engagement models, especially CBR. In their view, CBR challenged the implementation of PAR because CBR was seen to open the possibility of accepting different community-situated and action-oriented models of research.

This situation made the alumni of the previous programs in Canada feel responsible to answer the challenge. The first step taken was to invite a research expert from the Indonesian Institute of Sciences/Research (Lembaga Imu Pengetabuan Indonesia/LIPI) to discuss the philosophical and historical foundations of PAR and CBR. Another step was to conduct an extensive international literature review on the topic. In the end, we came to the conclusion that, on the one hand CBR and PAR could be used interchangeably to denote any orientedaction and community-based research, while on the other hand CBR was considered as a more current and general research term that included PAR.

Apparently, theoretical written resources were not enough to convince everyone to accept CBR. The SILE/LLD Project therefore invited the Centre for Community Based Research (CCBR), a nonprofit organization in Waterloo, Canada to be trainers for CBR. Multiple sessions over a three-year period (2014-2016) were held both in Indonesia and in Canada. In addition, the Project sent some faculty members to attend similar research training for community-led change at the Coady Institute. The idea was to bring in these different resources to show that CBR draws on a wide range of global traditions, from southern to northern to Indigenous research traditions. These different traditions need not conflict but can reinforce each other.

These efforts to bring different resources and activities to the university finally paid off. The university agreed to develop CBR to the next level. The previous level ranged from theoretical understandings of the CBR concept, to analyzing CBR practice. The next step was to develop CBR pilot projects and then evaluate these projects. In the end, the prior knowledge and experience with PAR proved helpful in building a strong CBR agenda.

Developing Community-Based Research Guidelines and Piloting

The acceptance of and enthusiasm for CBR by faculty members created a new need for the university to have its own contextualized CBR handbook and guidelines. The SILE/ LLD Project struck a CBR working team to develop and write two introductory books titled 1) "Community-based Research: An Introduction" (Pengantar CBR), and 2) "Communitybased Research: Guidelines for Planning and Implementation" (CBR: panduan perencanaan dan pelaksanaan). The first book (Hanafi 2005) was quite conceptual, based mainly on literature review and from information received during training from the Centre for Community Based Research (Ochocka and Janzen 2014). The second book (CBR Team 2016) was more practical and more grounded in CCBR resource materials. We engaged our community partners to review the books. The process of developing the books took longer than expected but the long process paid off, resulting in enhanced readability and usability of the books. The books were 
published nationally and distributed during the 2015 International Conference on UniversityCommunity Engagement (ICON-UCE) in Surabaya.

The second book was adopted by the Institute of Research and Community Service (Lembaga Penelitian dan Pengabdian Masyarakat/LPPM) through the Research Center in the University. Subsequently, the university allocated research grants to conduct CBR pilot projects. CCBR helped facilitate designated faculty members to develop research proposals with their community partners. Some of these were awarded funding by LPPM. The implementation of these projects was monitored by the Research Center to ensure the quality of the project. Finally, the projects were also evaluated using a self-assessment tool and framework for community-based research excellence developed by CCBR.

Above all, the university has become a CBR resource institution across the Islamic higher educational system in Indonesia. The Directorate of IHE invited CBR-experienced faculty members to train other lecturers from other universities across country to conduct community service and CBR.

\section{Community-Based Research and Institutional Policy}

The personal capacity-building of CBR in the university has progressed quite well. Some faculty members have come to see that research can be used as a means to attempt social transformation in a more systemic way because CBR engages not only community members but other stakeholders as well. The research also integrates Tridharma Perguruan Tinggi (i.e., the three mandates of higher education: teaching, research and community service) and strengthens the implementation of each mandate. Therefore, it became clear that the learnings about CBR now needed to be maintained through institutional policy and regulation.

The positive acceptance of CBR by senior university administrators was demonstrated through the positive action they took to include CBR within the university's strategic plan. This meant that the university now was responsible to grant and facilitate the implementation of CBR projects. Furthermore, the university's strategic plan also included an emphasis on university-community engagement. In other words, the university faculty members and students can now conduct CBR within the framework of Tridharma (the three university mandates). For example, they could use CBR through a community service-learning model while teaching, as a community service, or through the research dharma (mandate) itself. After the university had successfully placed CBR in its strategic plan, the Directorate of Islamic Higher Education under the Ministry of Religious Affairs started to adopt CBR into their policy statements as well. For example, the implementation of CBR is ensured in the Decree of the Director General of Islamic Education No. 4834 of 2015 containing Guidelines for Community Service in Institutions of Islamic Higher Education. The Directorate also included a conference on university-community engagement on its biennial agenda to celebrate and disseminate learnings from CBR projects and other community-university engagement innovation. Finally, the LPPM of the university is developing plans to launch a journal to more widely disseminate examples of community-university partnerships.

In an effort to maintain CBR best practices, and in order to keep up with the global 
movement of community-university engagement, the university decided to join the AsiaPacific University-Community Engagement Network (APUCEN). This is a network of academic institutions of higher learning concerned with promoting proactive, inclusive, holistic and participatory efforts to co-create knowledge that enhances the social, economic and environmental aspects of communities within the region of Asia-Pacific (https:/ / apucen. usm.my). The university and the Directorate also support faculty members to attend capacitybuilding activities related to CBR such as training, sessions, workshops, and conferences.

\section{Case 2: The Alauddin State Islamic University Makassar}

Makassar, often called Ujung Pandang, is the provincial capital of South Sulawesi and the most populous city in South Sulawesi. Located at the western tip of the island of Sulawesi, the city is a metropolitan area and one of the most populous urban centres in Indonesia. With a National Census Bureau-estimated population of 1,568,478 distributed over a land area of $175.77 \mathrm{~km}^{2}$ which lies adjacent to Makassar Strait, Makassar is also the most densely populated major city in Indonesia. Most of the population in Makassar is Buginese, Makassarese, Mandarese and Torajan. Every ethnicity has a different language with various dialects. Such ethnic diversity also spawned a variety of arts and cultural treasures that enrich traditional culture in Makassar. This diversity is a local cultural asset but at the same time can also be a threat to social cohesion.

UIN Alauddin is the only State Islamic Institution of Higher Education in Makassar. The university has focused mainly on Islamic education and learning since 1965. In 2005, during the era of national higher education reform, this institution converted to a State Islamic University and was named UIN Alauddin Makassar. This conversion was aimed at responding to the needs of Islamic society and ongoing changes in the national education system. Soon after the conversion, UIN Alauddin managed seven undergraduate faculties and graduate programs at both the masters and doctoral levels. The seven faculties are: Faculty of Shariah (Islamic jurisprudence) and Law; Faculty of Tarbiyah (Islamic education) and Teaching Science; Faculty of Ushuluddin (Islamic theology), Philosophy, and Politics; Faculty of Adab (Islamic culture and letters) and Humanities; Faculty of Dakwah (Islamic preaching) and Communication; Faculty of Science and Technology; Faculty of Health Sciences with a new additional study program of medicine in 2016; and Faculty of Economics and Islamic Business. As a higher education institution, UIN Alauddin is able to integrate Islam, science, technology, and art and to produce highly competitive graduates.

The Ministry of Religious Affairs (MORA) determines the university's organizational structure and management system. In addition to the various faculties and support services, the university has a Research Center and a Community Service Center. In 2013, these two Centers, plus the Center for Women's and Children's Studies and several new interdisciplinary centers, were combined into a new unit called the Institute for Research and Community Service (LPPM). As a result, this Institute has been given a position of higher prominence within the university, reporting directly to the Vice-Rector (Vice President). 


\section{Research and Islamic Values in Academic Settings}

The concept of CBR is in line with the intellectual and research traditions that occupy a significant position within Islam. The value of education and research in Islamic tradition is frequently highlighted in the Holy Qur'an with numerous injunctions, for example: "God will exalt those of you who believe and those who have knowledge to high degrees" (58:11); "As God has taught him, so let him write" (2:282); and, "O my Lord! Increase me in knowledge" (20:114). Those verses offer a vibrant inspiration for the Islamic community to value education.

In addition to those verses, a research tradition derived its origin from a verse in the Holy Qur'an, "O you who believe! If an evil-doer comes to you with important news, verify it, lest you should harm people in ignorance [out of haste in belief and decision-making], and afterwards you become regretful for what you bave done" (18:6). This verse, which is addressed to believers, suggests that if a wrong-doer comes with intelligence, the believer should not acknowledge it unless they investigate its accuracy or validity. Otherwise, believers may have done something wrong and unjust. Thus, even if the information transmitter is intelligent but a wrong-doer, a Muslim should not trust the information she/he imparted before investigating it. The transmitter him/herself must be honest and trustworthy. In short, human integrity is the most significant factor in the Islamic research tradition. CBR, with its emphasis on maintaining high standards of research integrity and excellence, can be viewed as one avenue of pursuing such an academic research agenda.

\section{Institutionalizing Community-Based Research on Campus}

When considering social change in relation to CBR we typically think first about its contribution to community change. However, another significant kind of transformation that CBR promises is within the university itself. CBR helps to define, support, and reward the university's historical mission of teaching, research, and community service. The key challenge faced by UIN Alauddin since the Reform Era was to foster active citizenship and civic engagement within a socio-political environment in which open democratic spaces are more common. An added level of sensitivity is for the university to promote such civic engagement in the Makassar region without being perceived as an agent or intermediary of foreign policy. As with other Islamic universities and institutions, UIN Alauddin may also face worries about terrorism, with many students at a vulnerable age for becoming targets for radicalization based on commonly misunderstood Islamic jihad concepts. Another controversial aspect of the university's Islamic conversion relates to the rejection of the Shi'ite group by some Islamic communities, and how this might play out on campus.

In a more immediate sense, CBR researchers call upon the institution, UIN Alauddin in this case, to provide organizational and administrative structures necessary to support and sustain CBR work and community partnerships. It is possible (and not uncommon) for individual faculty members to develop partnerships and involve students in CBR projects quite on their own, without any formal institutional supports. However, the different tasks connected with CBR are accomplished far more effectively when institutions formally organize to support this work. This can be done, for example, in the form of a program-based CBR office, a campuswide center, or even a local/regional consortium under the supervision of Lembaga Penelitian 
dan Pengabdian Masyarakat (LPPM - Institute of Research and Community Service). With the increasing scale of socio-cultural, political, and economic problems in the Makassar region, the scope for civic engagement has widened. Consistent with its vision statement, the role of UIN Alauddin is to promote social transformation and to contribute to developing an advanced Islamic civilization. To implement this vision, the university's civic engagement activities are mainly focused on conventional forms of voluntary service among students and faculty. However, there has been some experimentation with formal coursework that incorporate service-learning pedagogy that connect students' classroom learning with community service experience. With reforms emerging in the country during the reign of the last five national presidents, the university anticipates the possibility of introducing other forms of civic engagement in the future.

One example has been reforms in conducting research and community service in UIN Alauddin over the past three years (2014-2016). The university did this by participating in the SILE/LLD Project and learning about community-based research (CBR). Traditionally the academic community, particularly faculty members and students used a conventional approach to research in which community members were the objects of research. In this conventional approach, the researchers determined his/her own questions to be brought to the public and obtained data from citizens who were passive research objects. It turned out that this type of research did not effect changes in society as desired since societal problems were formulated by the researcher and not by community members. CBR, in contrast, articulates problems and solutions jointly by researcher and the community. It was therefore very crucial to introduce CBR to faculty members and students of UIN Alauddin so they could implement and conduct this approach to research.

The CBR model was introduced through a series of training sessions. Similar to UIN Sunan Ampel in Surabaya, the SILE/LLD Project made arrangements for the Centre for Community Based Research (CCBR) to provide CBR training and coaching for numerous faculty, staff and community partners of UIN Alauddin. The training was held in Canada and in Indonesia and was well received. CBR was subsequently incorporated into required Research Methodology course curricula as a new approach to conducting research through community involvement. The course was offered as a compulsory subject across all faculties. In addition, the Center for Research and Community Service at UIN Alauddin identified CBR as one type of research to be conducted by faculty members. In 2015 four CBR proposals were selected to be funded by the Center with expectations that the research would be collaborative and changeoriented. The Centre sought to engage faculty members, students, and community members in research that addressed a community-identified need. The research differed in important ways not only from traditional academic research, but also from the sort of "charity-oriented" service-learning that has come to be practiced and promoted at many universities. Indeed, the distinctive combination of collaborative inquiry, critical analysis, and social action that CBR entails made it a particularly engaging and transformative approach to teaching and research. Moreover, its potential to unite the three traditional academic missions of teaching, research, and community service in innovative ways made it a potentially revolutionary strategy for 
achieving long-lasting and fundamental institutional change.

It did not take long for those trained in CBR to share their learnings with others on the campus and beyond. For example, in 2016 CBR "training alumni” shared information about CBR to other UIN Alauddin faculty members from eight departments. A meeting was held to introduce CBR and other SILE/LLD products to faculty members in attempt to institutionalize CBR on campus. Beyond the campus, in 2015 CBR training alumni provided training for faculty members who had

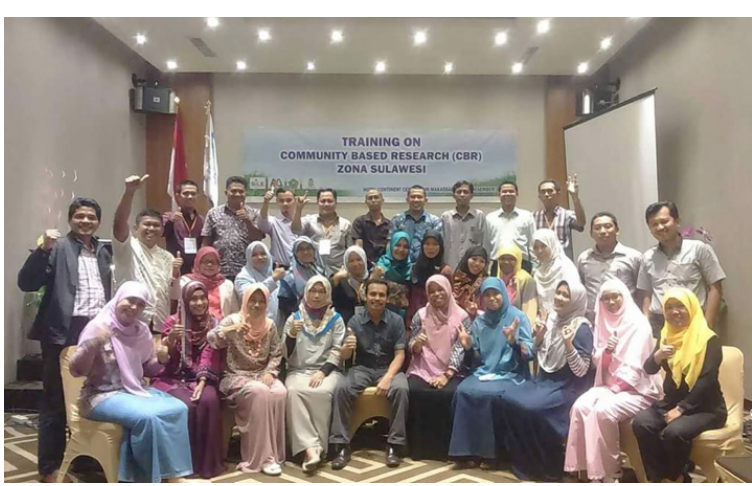

Figure 1: Photo Session with the Committee and Participants of the CBR Training. won CBR research grants provided by the Ministry of Religious Affairs (MORA) of Indonesia. All researchers receiving grants were required to participate in a two-day CBR orientation held in Makassar and facilitated by the CBR alumni through the ACCED (Alauddin Center for Community Engagement and Development). There were about thirty faculty members from Eastern Indonesian Islamic Higher Education Institutions who were very enthusiastic and newly exposed to CBR. Following the successful training, CBR training alumni were invited to give CBR training to faculty members at IAIN (State Islamic Institution) Ternate. This was a great achievement as this institution is $1,995 \mathrm{~km}$ from Makassar in the eastern part of Indonesia. The next CBR workshop was carried out in 2016 in collaboration with a well-known civil society organizations in Makassar called Forum Pemerhati Masalah Perempuan (Forum for Activists Concerned with Women's Issues). This three-day workshop involved 40 members of the organization across South Sulawesi Province. Some workshop participants had been very much involved with CBR projects for years even though it was the first time for them to hear the CBR term being used. Finally, CBR workshops were delivered for faculty members of STAIN Watampone, one of the Islamic Higher Education Institutes in South Sulawesi. The workshop ran for two days attended by 100 faculty members of the institution who were eager to adapt and adopt CBR into their research. At the end of the training, the head of Center for Research and Community Outreach of the institution announced to the participants that CBR would be accommodated as one group of research grants for faculty members pursuing research.

\section{Reflection on Community-Based Research Institutionalization}

The experience of institutionalizing CBR in both UIN Sunan Ampel and UIN Alauddin was quite adventurous. It progressed through a lengthy process that covered a variety of transformational phases from raising awareness, to building capacity, to piloting projects, and finally to making policy. It involved intense philosophical-ideological debates and emotional conflicts among the faculty members as well. 
As religious higher education institutions that have had a strong commitment to social transformation from their early establishment, both universities are open to adopting ideas that support their vision to promote a just, equal, prosperous, and dignified society. However, the universities still need to have a critical understanding of the socio-historical and political contexts, both globally and locally, to best implement these ideas. Apparently both universities have so far had the capacity to adapt and change according to their unique situations. For example, the initial adoption of PAR as an approach to research during the Indonesian Reform Era was politically strategic because it was in line with the spirit of the era to decentralize power to local governments and endorse the broader participation of citizens within developmental plans.

The first encounter with CBR was at CUExpo 2013, followed by a short internship program in ICES at the University of Guelph, and an extensive literature review. However, the universities realized that these brief experiences were not enough to have CBR institutionalized

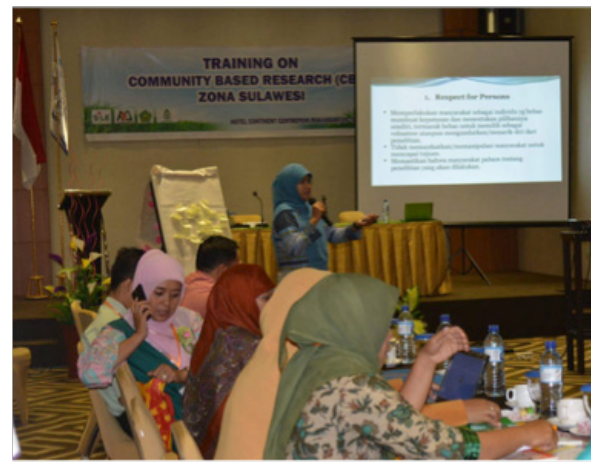

Figure 2: Facilitating CBR Training to the Lecturers of the Eastern Islamic Higher Education of Indonesia formally within university policy. Therefore, in response to university recommendations, the SILE/LLD project invited the Centre for Community Based Research (CCBR) to provide a series of $\mathrm{CBR}$ capacity-building training and coaching opportunities.

Having CBR training delivered by CCBR from Canada, as a first-hand practitioner, was a great success because they began by introducing the guiding principles of this approach to research before discussing its practical steps. The principles were packed with catchy phrases such as the three hallmarks of CBR: communitydetermined, participatory and action-oriented (www.communitybasedresearch.ca). These principles were well accepted and appreciated by the workshop participants because they corresponded to Islamic basic teachings, such as transforming the Ummah (Muslim community) into a way of better living. Training participants including religious community leaders, civil society leaders, and faculty members who believed that CBR could be utilized to bring about social change, and in a more effective way than the "missionary approach" that had been typically carried out through traditional preaching or lecturing.

The exposure to CBR as an activity within the broader conceptualization of communityuniversity engagement and partnership was an insightful moment. There was a recognition that CBR can be seen as an all-inclusive, blanket term that covers different global theories, traditions, and disciplines. The term could also accommodate the existing different practices of community-engaged enterprises on the campuses.

To this end, the prevalence of PAR over a decade ago in Islamic Higher Institution in Indonesia played a double role. The first role was to effectively assist the acceptance of CBR 
by academics because of the similarities of these two models of research. Both promote social change and social justice. The second role was to challenge the advance of CBR as another form of academic colonialization from the West.

As a result, we have tried not to make an unnecessarily distinction between PAR and CBR. Instead, we follow Robert Chambers' (1992) insight to look at the differences among the oriented-action, community-based and participatory researches "like flows in a braided stream, intermingled more and more”. In addition, we also follow Randy Stoecker's (2003) standpoint on CBR "as a popular model of community-higher education collaboration that combines various forms of action-oriented research with service-learning to support social action for social justice." Indeed, the CBR concept includes two different theoretical strands; the first is charitable service-learning and an action research combination ("mainstream CBR") and the second is social justice service-learning and a participatory research combination ("radical CBR"). Any worries of CBR being a new form of colonialism were eased it was shown that one initial source of CBR was understood to originate from Tanzania, Africa (Hall 2005).

In general, the academics on our campuses showed a positive attitude towards CBR. Their positive attitude came out of a belief that with CBR, they could maximize vital aspects of Islam as being a religion that is responsible for social justice and peace. They could exemplify the transformative power of Islam in democratic ways as it is mandated by the Holy Qur'an to have Ummah consultation. Furthermore, they could incorporate Islamic teaching that highly praises action-taking for the common good.

In terms of practical implementation, CBR was perceived as a moderate, flexible and yet rigorous model of research. There is no specifically-ordered set of tools that are mechanically applied because CBR places priority on the unique context and situation of each community without neglecting research rigour. For both universities, what really matters in the implementation of CBR is that it corresponds to Islamic teaching to follow the principle of "do no harm" as noted in the Islamic law principle, la dharar wa la dhirar (no harm and no harming). Due to the importance of this principle, we felt that a research ethic was needed that would seek community safety and dignity.

Recently, the resources arising out of the SILE/LLD Project (e.g., the books developed, the pilot research projects and the capacity-building participants themselves) within both universities have become helpful in incorporating CBR within the national research policies of the Directorate of Islamic Higher Education under Ministry of Religious Affairs of the Republic of Indonesia. The adoption of CBR elements within national policy now plays an important role in sustaining the spirit and practice of CBR more systematically. For example, the Directorate enacted new regulations of community engagement and declared that CBR can be used as one model of research when applying the Tridharma of Higher Education. In this way, we hope that CBR can be sustained and disseminated into other Islamic higher education institutions across Indonesia. Moreover, we wish to join the global movement of CBR networks in transforming the world into a more just and peaceful place to live. 


\section{Conclusion}

These two state Islamic universities have undergone similar capacity-building on CBR. The SILE/LLD Project treated both universities equally in almost every aspect of the institutionalization process, from raising local CBR awareness to making national policy. However, the individual response to program involvement was not always similar because each university had its own unique socio-historical context and internal political dynamic. Interestingly, the two campuses share similar reasons for adopting CBR from an Islamic perspective, namely that using research as a means of promoting social change is consistent with the Qur'anic principles and the Prophetic tradition.

CBR institutionalization in UIN Alauddin was challenged by conventional research with its positivistic paradigm that views community members as mere objects of research. This notion contradicts CBR where community members can play different roles within a research project, whether that be as participant, data enumerator, organizer, or even researcher. In contrast, UIN Sunan Ampel faced the challenge of reconciling two similar research approaches (i.e. PAR and CBR). The proponents of the well-established PAR approach in Surabaya questioned the CBR paradigm and criticized it as lacking an emancipatory spirit. Surprisingly, there were no challenges or resistance to CBR within either campus based on Islamic arguments.

Despite the different challenges and responses, both campuses share a common basic agenda of institutionalizing CBR in Islamic higher education institutions. They also agree that efforts are needed to incorporate CBR into national research policy through the Directorate of Islamic Higher Education. This national research policy institution now endorses the application of CBR amongst Islamic higher education institutions across the country. We believe that such systemic policy will make it more likely that CBR becomes sustainable in Indonesia.

\section{About the Authors}

Djuwairiah Ahmad is a senior lecturer at the Faculty of Education and Teacher Training, the Alauddin State Islamic University of Makassar, South Sulawesi, Indonesia. Her majoring is English Language Teaching and is currently the head of Center for Languages Development at the university.

Mohammad Hanafi (corresponding author) is a faculty member of Sunan Ampel State Islamic University Surabaya's Faculty of Education and Teacher Training. Email: hanafibeta@gmail. com 


\section{References}

CBR Team (2016). Community-based research: Panduan teknis. Surabaya, Indonesia: LP2M UIN Sunan Ampel Press.

Chambers, R. (1992). Rural appraisal: Rapid, relaxed and participatory (Discussion Paper No. 311.), Brighton, U.K.: Institute for Development Studies. Retrieved from https://www.ids.ac.uk/ files/Dp311.pdf.

Hall, B. L. (2005). In from the cold? Reflections on participatory research from 1970-2005. Retrieved from: http://www.niace.org.uk/publications/Periodicals/Convergence/.

Hanafi, M. (2015). Community-based Research: Sebuah pengantar. Surabaya, Indonesia: UIN Sunan Ampel Press.

Ochocka, J., \& Janzen, R. (2014). Breathing life into theory: Illustrations of community-based research hallmarks, functions, and phases. Gateways: International Journal of Community Research and Engagement. 7, 18-33.

Stoecker, R. (2003). Community-based research: From practice to theory and back again, Michigan Journal of Community Service Learning, 35-46. Retrieved from: http://www.richardswanson. com/textbookresources/wp-content/uploads/2013/08/TBAD-r8-Community-BasedResearch-R.-Stoeker-2003.pdf. 